\title{
Proximate Composition, Colour Characteristics, Index of Oiliness and Estimated Glycemic Index of Deep-fried Bitter Yam (Dioscorea dumentorum) Chips
}

\author{
Mathew K. Bolade ${ }^{1}$, Mohammed A. Usman², Ufuosuo Da- \\ Clarke $^{1}$
}

\author{
${ }^{1}$ Department of Food Science and Technology, Federal University of Technology, P.M.B. 704, Akure, Ondo State, \\ Nigeria \\ ${ }^{2}$ Department of Food Science and Technology, Modibbo Adama University of Technology, P.M.B. 2076, Yola, \\ Adamawa State, Nigeria
}

\begin{abstract}
The study investigated the potential production of fried chips from bitter yam (Dioscorea dumentorum) as well as the evaluation of quality characteristics of the chips. Yellow and white bitter yam and sweet potato (control) obtained from a local yam farmer were respectively processed into fried chips while the chips were subsequently subjected to analysis. The results showed that the proximate composition of fried bitter yam ranged as follows: moisture content $(5.32-6.04)$, fat $(28.93-29.41)$, ash $(1.66-1.82)$, fibre $(4.45-7.38)$, protein $(2.44-3.32)$ and carbohydrate $(58.71-61.85 \mathrm{~g} / 100 \mathrm{~g})$. The proximate composition of fried sweet potato chips was moisture content (4.64), fat (28.51), ash (2.91), fibre (6.01), protein (0.55) and carbohydrate (62.04 g/100g). Frying operation was found to cause decrease in the proximate values except fat value due to oil absorption. The browning indices of the fried chips from yellow and white bitter yam and sweet potato were 66.2, 50.8 and 52.8, respectively while the values for oiliness indices were $29.1,21.6$ and $36.1 \mathrm{~cm}^{2}$, respectively. The rate of in vitro starch digestibility of the fried chips revealed the following order: yellow bitter yam > white bitter yam > sweet potato. The hydrolysis indices were $72.5,63.1$ and $58.4 \%$ while their corresponding estimated glycemic indices (eGI) were 79.5, 74.4 and $71.8 \%$ respectively, all indicating high glycemic index values. The sensory quality rating of the fried products revealed that chips from sweet potato was rated the highest in terms of aroma, taste, colour and overall acceptability but not significantly different $(\mathrm{p}<0.05)$ from that of yellow bitter yam. Therefore, the use of yellow bitter yam for commercial production of fried chips, as a way of utilization diversification and value addition, is recommended.
\end{abstract}

Keywords: Bitter Yam, Fried Chips, Browning Index, Glycemic Index, Digestibility

\begin{abstract}
Introduction
Yam (Dioscorea spp.) is a tuber crop that is very important in the diets of people in the tropics and many parts of the subtropics and temperate zones (Kordylas, 1990, Akissoe et al., 2003). It is a readily available carbohydrate source for the consumers in the regions of production (Babajide et al., 2008). Yam is one of the primary agricultural commodities particularly in West Africa where it serves as a key staple food in such countries as Nigeria, Benin, Togo, Ghana and Sierra Leone (Ile et al., 2006; Baimey et al., 2006). The production of yam globally is more than 65 million tonnes fresh tuber per annum while more than $90 \%$ of this output usually come from
\end{abstract}

\begin{abstract}
West Africa (FAOSTAT, 2014). There are over 150 yam species cultivated globally (Purseglove, 1991) while the commonly grown species in West Africa include Dioscorea alata, Dioscorea rotundata, Dioscorea dumentorum and Dioscorea liebrechisiana, among others (Agbor-Egbe and Treche, 1983). Yam production by farmers essentially plays a crucial role in their food security, income generation, and culture of the people (Washaya et al., 2016). In spite of large production output of yam emanating from West Africa, the commercial utilization of yam still remains at the level of traditional usage of boiled, fried, roasted, baked, and mashed yam consumption; flour and
\end{abstract}

This article is published under the terms of the Creative Commons Attribution License 4.0

Author(s) retain the copyright of this article. Publication rights with Alkhaer Publications.

Published at: http://www.ijsciences.com/pub/issue/2017-11/

DOI: 10.18483/ijSci.1468; Online ISSN: 2305-3925; Print ISSN: 2410-4477 
pounded yam preparation, and instant yam flour production. (Onwueme and Charles, 1994; Osunde, 2008).

In Nigeria, the utilization of yam is even found to be highly concentrated on some species such as Dioscorea rotundata, Dioscorea cayenensis, and Dioscorea esculenta; while others seemingly have minimal usage and these include Dioscorea alata (water yam) and Dioscorea dumentorum (bitter yam), among others. The production of fried chips from tuber crops such as Dioscorea rotundata, Dioscorea esculenta and sweet potato is a common scene in Nigeria. These fried chips are usually taken as snacks which have been described as foods usually consumed to provide light sustenance in a quick and convenient format (IFIS, 2009). Snacks are also normally consumed between or as an alternative to main meals. The use of sweet potato for commercial fried chip production is currently increasingly popular in Nigeria. It had earlier been observed that in order of enhance the role of yam in food diversification and income generation; there is the need to make use of the seemingly underutilized yam species by way of value addition (Maziya-Dixon et al., 2014).

The objective of this study therefore was to evaluate the possibility of producing fried chips from Dioscorea dumentorum (bitter yam) with a view to diversifying its usage as well as assessing its quality attributes and consumer's acceptability.

\section{Materials and Methods}

\section{Materials}

The white and yellow bitter yam tubers (Dioscorea dumentorum) used for the study were obtained from the farm of a yam farmer at Ilara-Mokin, Ondo State, Nigeria while the white sweet potato tubers (Ipomoea batatas) were purchased from Oja-Oba market, Akure, Ondo State, Nigeria. The sweet potato was used in the study to serve as the control.

\section{Preparation of deep-fried bitter yam chips}

The white and yellow bitter yam tubers were respectively peeled and sliced, in circular shape, using a domestic potato slicer which was set to a thickness of $2 \mathrm{~mm}$. The slices were then washed in water, drained properly and salted followed by deepfrying in vegetable oil (Executive Chef brand) at a temperature of $180 \pm 2{ }^{\circ} \mathrm{C}$ in a commercial deep fryer for $7 \mathrm{~min}$ with intermittent turning of the chips. The deep-fried chips were then subjected to draining, cooling and packaging in transparent polyethylene. Sweet potato was similarly subjected to the deep frying process to obtain fried sweet potato chips which served as the control.

\section{Determination of proximate composition of fried bitter yam chips}

The fried chip samples were analysed, in triplicate, for moisture, ash, crude fat, crude protein and fibre contents using Association of Official Analytical Chemists' methods (AOAC, 1990). Carbohydrate was estimated by difference.

\section{Determination of colour characteristics of fried bitter yam chips}

The colour of fried chip samples from each tuber source was measured using a colour measuring instrument (ColorTec-PCM, model SN 3000421, Clinton, NJ, USA) and the values expressed on the $L^{*}, a^{*}, b^{*}$ tristimulus scale. The colour values were expressed as $\mathrm{L}^{*}$ (whiteness or brightness/darkness), $\mathrm{a}^{*}$ (redness/greenness) and $\mathrm{b}^{*}$ (yellowness/blueness) respectively (McGuire, 1992). The instrument was first standardized $\left(\mathrm{L}^{*}=94.11, \mathrm{a}^{*}=0.97, \mathrm{~b}^{*}=-2.62\right)$ with a white photocopying paper $\left(80 \mathrm{~g} / \mathrm{m}^{2}\right)$.

The browning index (BI) of the fried chips was calculated from the $\mathrm{L}^{*}, \mathrm{a}^{*}, \mathrm{~b}^{*}$ tristimulus scale and used to describe the brown colour characteristics of the sample (Maskan, 2001):

Browning Index $(\mathrm{BI})=\frac{[100(\mathrm{x}-0.31)]}{0.17} \ldots \ldots \ldots \ldots . .$. Eq. (1) where,

$x=\frac{(a *+1.75 L *)}{(5.645 L *+a *-3.012 b *)}$

\section{Evaluation of index of oiliness in fried bitter yam chips}

The method of Da-Clarke (2016) was adopted. Fried chips from each tuber source were evaluated for their index of oiliness by placing a circular-shaped fried chip at the centre of a large white filter paper $(18 \mathrm{~cm}$ in diameter) which was also placed on a flat, nonabsorbent platform. The central point of the sample was noted when placed on the paper while the fried chip sample was left to stay on the filter paper for $2 \mathrm{~h}$ after which the circular spread of the oil absorbed by the filter was measured. The index of oiliness in the fried chip sample was taken as the total circular area $\left(\mathrm{cm}^{2}\right)$ occupied by the oil absorbed by the filter paper from the sample. The experiment was carried out in triplicates while the average total circular area occupied by the absorbed oil was taken as the actual index of oiliness $\left(\mathrm{cm}^{2}\right)$ of the sample. This evaluation assumes a circular movement of the absorbed oil.

Calculation:

Index of oiliness $\left(\mathrm{cm}^{2}\right)=$ Total circular area occupied by the absorbed oil

$=\pi R^{2}-\pi \mathrm{r}^{2}$

$=\pi\left(R^{2}-\mathrm{r}^{2}\right) \ldots \ldots . . .$. Eq. 1

where;

$\mathrm{R}=$ outer radius of circular distance travelled by the absorbed oil (cm)

$r=$ radius of internal circular space unoccupied by the absorbed oil (cm)

$\pi=$ constant factor $(3.142)$ 


\section{Evaluation of in-vitro starch digestibility of fried bitter yam chips}

The in vitro starch hydrolysis rate of fried chips was determined according to Goni et al. (1997). One gramme $(1 \mathrm{~g})$ of the blended chips was incubated with $0.2 \mathrm{ml}$ of pepsin in $10 \mathrm{ml}$ distilled water and $0.005 \mathrm{~g}$ of $\alpha$-amylase was added at $37^{\circ} \mathrm{C}$ in a shaking water bath. Exactly $0.1 \mathrm{ml}$ sample was taken from the flask every $30 \mathrm{~min}$ from $0 \mathrm{~h}$ to $3 \mathrm{~h}$ and boiled for 15 min to inactivate the enzyme. Sodium acetate buffer $(1 \mathrm{ml} 0.4 \mathrm{M}, \mathrm{pH} 4.75)$ was added and the residual starch digested to glucose by adding $30 \mathrm{ml}$ amyloglucosidase and incubating at $60{ }^{\circ} \mathrm{C}$ for 45 min. Glucose concentration was determined by adding $200 \mathrm{ml}$ of dinitrosalicylic acid colour reagent. The reaction mixtures was stopped by placing the tubes in a water bath at $100{ }^{\circ} \mathrm{C}$ for $5 \mathrm{~min}$ and then cooled to room temperature. The reaction mixture was then diluted by adding $5 \mathrm{ml}$ of distilled water and the mixture was centrifuged at $1200 \mathrm{x} \mathrm{g}$. The supernatant was collected and the absorbance measured at $540 \mathrm{~nm}$ using spectrophotometer. The extent of hydrolysis was expressed as the percentage of starch hydrolyzed to glucose (glucose equivalent) at different incubation times. A $50 \mathrm{mg}$ sample of glucose was used as the standard. One gramme $(1 \mathrm{~g})$ of white bread was similarly subjected to in vitro starch hydrolysis to serve as a reference.

\section{Determination of estimated glycemic index of fried bitter yam chips}

Using the hydrolysis curve $(0-180 \quad \mathrm{~min})$, the hydrolysis index (HI) was calculated as the percentage of total glucose released from the samples compared to that released from white bread (Granfeldt et al., 1992). The glycemic indices of the fried samples were estimated according to the equation of Goni et al. (1997):

Where, $\quad$ eGI $=39.71+0.549\left(\mathrm{HI}_{[180]}\right) \ldots \ldots \ldots . .$. Eq. (3)

eGI= estimated glycemic index, and

$\mathrm{HI}_{[180]}=$ hydrolysis index (percentage of total glucose released from the samples compared

to that released from white bread at 180 min hydrolysis).

\section{Sensory quality assessment of fried bitter yam chips}

Fried chips from various tuber sources were evaluated for their sensory qualities and general acceptability. A scoring test was used which was designed to determine which of the products was most preferred. A 50-member semi-trained taste panel was requested to carry out the rating of the fried chips. The panelists were all familiar with the food product while they were also instructed on the use of sensory evaluation procedures. The fried product was presented to each panelist when its temperature was at ambient level $\left(30 \pm 2^{\circ} \mathrm{C}\right)$. Each of the panelists was asked to rate the samples on the basis of colour, taste, degree of oiliness, aroma, crispiness and overall acceptability using a nine-point hedonic scale (i.e. $9=$ like extremely; $5=$ neither like nor dislike; 1 = dislike extremely). The scores from the rating were subsequently subjected to analysis of variance (ANOVA) and the means separated using Duncan Multiple Range test (IFT, 1981; Lawless and Heymann, 2010).

\section{Statistical analysis}

All determinations carried out were done in triplicates. A mean value and standard deviation were calculated in each case. Analysis of variance (ANOVA) was also performed and separation of the mean values was by Duncan's Multiple Range Test at $\mathrm{p}<0.05$ using Statistical Package for Social Scientists (SPSS) software, version 16.0.

\section{Results and Discussion}

\section{Proximate composition of fried chips from bitter yam}

The proximate composition of fried chips from yellow and white bitter yam and sweet potato is presented in Table 1. The moisture content of raw unfried chips ranged between 76.29 and $81.31 \mathrm{~g} / 100 \mathrm{~g}$ while, after frying, the moisture contents of the chips from yellow bitter yam, white bitter yam and sweet potato were $6.04,5.32$ and $4.64 \mathrm{~g} / 100 \mathrm{~g}$, respectively with significant differences $(\mathrm{p}<0.05)$. The variability in the final moisture content in the fried chips may be due to different initial moisture levels in the raw unfried chips which underwent evaporation during deep frying. An earlier observation had stated that a high temperature of frying usually led to the evaporation of water at the surface of the food (Bouchon and Aguilera, 2001).

The fat content of raw unfried chips ranged between 1.76 and $2.45 \mathrm{~g} / 100 \mathrm{~g}$ while that of fried chips from yellow bitter yam, white bitter yam and sweet potato were $29.41,28.93$ and $28.51 \mathrm{~g} / 100 \mathrm{~g}$, respectively with significant differences $(p<0.05)$. The higher oil uptake as observed in fried chips of yellow bitter yam may be attributed to a possible higher oil absorption capacity of the chips. The oil uptake by a food product undergoing frying is usually regarded as a function of volume of oil in the fryer, residence time in the fryer and mass transfer capacity of the product involving oil-water exchange and replacement (Sulaeman et al., 2001, Rojas-Gonzalez et al., 2006). The significance of higher oil content in the fried chips is that it can lead to a rapid induction time for rancidity to occur (Ikoko and Kuri, 2007). 
The ash content of raw unfried chips from yellow and white bitter yam and sweet potato were 7.59, 9.89 and $7.64 \mathrm{~g} / 100 \mathrm{~g}$, respectively while that of fried chips counterpart ranged between 1.66 and $2.91 \mathrm{~g} / 100 \mathrm{~g}$. The significant reduction of ash content in the fried chips may be attributed to the dilution occurrence of the chips with the absorbed oil during frying. The ash content is an index of totality of mineral elements in the food product while variability is attributable to diverse botanical origins (Marshall, 2010).

The crude fibre content of raw unfried chips ranged between 9.07 and $12.78 \mathrm{~g} / 100 \mathrm{~g}$ while that from fried chips of yellow bitter yam, white bitter yam and sweet potato were $4.45,7.38$ and $6.01 \mathrm{~g} / 100 \mathrm{~g}$, respectively with significant differences $(\mathrm{p}<0.05)$. The crude fibre is usually composed of cellulose, hemicelluloses and lignin, among others (Philips and Cui, 2011), and so the high frying temperature of the chips might have caused some degrees of destruction in the fibre components thereby leading to reduction in the overall content. The dilution effect of the absorbed oil during frying might have also contributed to the reduction in the absolute value of the crude fibre content. It had earlier been observed that some of the occurrences during the frying stage of a food product include the dehydration of cells located in the forming crust as well as breakdown of cellular adhesion (Bouchon and Aguilera, 2001). The nutritional significance of fibre in human diets include promotion of beneficial physiological effects such as laxation, blood cholesterol and glucose mitigation (BeMiller, 2010; Sanchez-Muniz, 2012), among others.

The protein content of raw unfried chips from yellow and white bitter yam and sweet potato were 11.88 , 10.08 and $7.93 \mathrm{~g} / 100 \mathrm{~g}$, respectively while that of fried chip counterpart were $2.44,3.32$ and 0.55 $\mathrm{g} / 100 \mathrm{~g}$, respectively with significant differences $(p<0.05)$. A reduction was observed in the protein content of the chips after frying which may be attributed to protein denaturation at high frying temperature and occurrence of complex reactions involving protein and lipid thereby leading to the formation of new compounds and generation of aroma and flavour (Funes and Karel, 1981; Pedreschi et al., 2005; Tumuluru et al., 2013).

The carbohydrate content of raw unfried chips ranged between 66.31 and $69.76 \mathrm{~g} / 100 \mathrm{~g}$ while that of fried chips from yellow bitter yam, white bitter and sweet potato were $61.85,58.71$ and $62.04 \mathrm{~g} / 100 \mathrm{~g}$, respectively with significant differences $(\mathrm{p}<0.05)$. The reduction in the carbohydrate content of fried chips may be due to starch gelatinization at high frying temperature (Bouchon and Aguilera, 2001) and possible migration of free soluble sugars from food to water within the material itself followed by the flow of such water into the frying oil (Guoado et al., 2011). It had earlier been observed that the complexity associated with frying is such that it involved mass transfer which is usually related to oil absorption and water loss together with soluble molecules (Sulaeman et al., 2001; Ikanone and Oyekan, 2014).

\section{Colour characteristics and oiliness index of fried chips}

The colour characteristics and oiliness index of fried chips from bitter yam and sweet potato are shown in Table 2. The lightness index ( $\mathrm{L}^{*}$-value) of the fried chips were 49, 56 and 54 for yellow bitter yam, white bitter yam and sweet potato respectively, with significant differences $(\mathrm{p}<0.05)$. However, the $\mathrm{L}^{*}$ value may not be a good indicator to describe the colour characteristics of a fried product which is naturally expected to develop a brown colouration during frying. Therefore, the browning index of fried chips from yellow bitter yam, white bitter yam and sweet potato were 66.2, 50.8 and 52.8, respectively, with significant differences $(p<0.05)$. The brown pigment formation from the fried chips may be attributed to possible caramelisation of sugar component present in the material being fried (Zhang et al., 2015). The formation of brown pigment such as melanoidins, through Maillard reaction between sugars and amino groups, may be promoted during high temperature frying (Fiore et al., 2012). The degree of brown pigment formation during frying can be influenced by such factors as type of vegetable oil involved in the frying and botanical origin of the plant material, among others (Krokida et al., 2001). The colour of a food product plays a significant role in the overall acceptability of such product by the consumers (Ikoko and Kuri, 2007).

The oiliness index of the fried chips from bitter yam and sweet potato also revealed that fried chips from sweet potato had the highest oiliness index of 36.1 $\mathrm{cm}^{2}$ while that from white yam had the lowest value of $21.6 \mathrm{~cm}^{2}$ (Table 2). The oiliness index essentially connotes the amount of oil capable of oozing out of the product into its surrounding environment such as when it is being handled by a consumer. This differs from the term 'oil content' which simply implies a measure of totality of oil in the product. The significance of oiliness index of a fried product is that it can influence the degree of acceptability of the product by the consumers while the oil content has implication on storability of the product. Therefore, lower oiliness index of a fried product implies that the absorbed oil in the product has a lower migrating capacity into its surrounding environment 


\section{In vitro starch digestibility and estimated glycemic index of the fried chips}

The rate of in vitro starch digestibility of fried chips from bitter yam and sweet potato in comparison with that of white bread is presented in Figure 1. It was observed that the in vitro starch digestibility was in the following order: white bread>yellow bitter yam>white bitter yam $>$ sweet potato. The total glucose released during the 180-min hydrolysis from white bread (reference), fried chips from yellow bitter yam, white bitter yam and sweet potato were 130.4, $94.6, \quad 82.3$ and $76.2 \mathrm{mg} / \mathrm{g}$, respectively with significance differences $(\mathrm{p}<0.05)$. One major factor to which variability in starch digestibility had been attributed is the botanical origin of the starch which plays a role in its hydrolysis in terms of morphological and structural differences (Faulks and Bailey, 1990; Simsek et al., 2012). Other factors capable of influencing in vitro starch digestibility of a food product include the extent of starch gelatinization (Chung et al., 2006) and the degree of non-digestible constituents in the food material (vander-Merwe et al., 2001). It had earlier been observed that the induced gelatinization by the processing methods such as boiling, baking or frying could permanently disrupt the starch complex, thus making it more readily accessible by the digestive enzymes (Bahado-Singh et al., 2011). The implication of lowest value of in vitro starch digestibility as observed in sweet potato is that it has a tendency of lowering glucose release into the blood stream, when ingested, which is advantageous to diabetic patients (Zia-Ul-Haq et al., 2007).

The estimated glycemic index (eGI) of fried chips from bitter yam and sweet potato revealed the following order: yellow bitter yam>white bitter yam>sweet potato (Table 3). Glycemic index is a term that describes the blood glucose response after consumption of a carbohydrate-containing test food relative to a carbohydrate-containing reference food, typically glucose or white bread (Venn and Green, 2007). The glycemic index values are usually classified as high (70-100\%), intermediate (55-69\%) or low (less than 55\%) (Bahado-Singh et al., 2011); and therefore, the estimated glycemic index (eGI) of fried chips from yellow bitter yam $(79.5 \%)$, white bitter yam $(74.4 \%)$ and sweet potato $(71.8 \%)$ were all of high category. The factors that can influence the variability in the glycemic index of food materials include method of food preparation/cooking (Odenigbo et al., 2012); amylose-amylopetin ratio in the food material (Miller et al., 1992) and the level of resistant starch in the food (Tufvesson et al., 2001), among others. The hydrolysis index (HI) of the fried chips also ranged between 58.4 and $72.5 \%$ with significant differences $(\mathrm{p}<0.05)$. The fried chips from yellow bitter yam exhibited the highest $\mathrm{HI}$ value while that from sweet potato had the lowest value.
The hydrolysis index is a parameter that is related to digestibility and used for the estimation of the glycemic index while its value is usually directly proportional to the estimated glycemic index value (Simsek et al., 2012).

The significance of the estimated glycemic index (eGI) in human nutrition is that carbohydrate foods with different glycemic index values will elicit dissimilar physiological effects when consumed (Riley et al., 2008). Similarly, the consumption of excess high glycemic index foods could lead to physiological challenges such as hyperinsulinemia, insulin resistance, weight gain, and possible obesity thereby capable of leading to insulin resistant syndrome (Ludwig et al., 1999; Wolever, 2000; vanBaak and Astrup, 2009).

\section{Organoleptic quality of fried chips from bitter yam}

The sensory quality rating of fried chips from biter yam and sweet potato is shown in Table 4. Fried chips from sweet potato was rated the highest in terms of aroma, taste, colour and overall acceptability but not significantly different $(\mathrm{p}<0.05)$ from chips from yellow bitter yam. Fried chips from yellow bitter yam was rated the highest in term of crispness while that from white bitter yam was rated the highest in terms of degree of oiliness. The sensory evaluation of a food has been recognized as an important tool in food product development. The data generated from sensory evaluation could serve as an index for predicting consumer's acceptability as well as a measure of economic strength of the product (Cardello, 1995; Moskowitz, 1995). Sensory evaluation could also be used to determine shelf life and product variability through the supply chain (Kemp et al., 2009). In addition, sensory evaluation could be used to set consumer acceptability limits for sensory specifications used during quality testing (Weller and Stanton, 2002).

\section{Conclusion}

The use of bitter yam (Dioscorea dumentorum) for producing fried chips essentially served as a means of diversifying its local utilization such that a value addition could be accomplished. The study had revealed that it is practically feasible to produce fried chips from bitter yam whose quality characteristics can compare favourably with common fried chips such as that of sweet potato. These quality characteristics include the proximate composition, colour in terms of browning index, oiliness index, estimated glycemic index (eGI) and consumer's acceptability. Therefore, commercial production of fried chips from bitter yam has the potential of creating an enhanced economic activity for the people as well as improved food security level for the producer. 


\section{References}

1. Agbor-Egbe, T. and Treche, S. (1983). Variability in the the chemical composition of yams grown in cameroon. In: Tropical Root Crops: Production and Uses in Africa (Terry, E.R., Doku, E.V., Arene, O.B. and Mahungu, N.M., eds). Proceedings of the Second Triennial Symposium of the International Society for Tropical Root Crops- Africa Branch, Held in Douala, Cameroon, 14-19, August, 1983; pp. 153156.

2. Akissoe, N.H., Hounhouigan, J.D., Mestres, C. and Nago, M. (2003). How blanching and drying affect the colour and functional characteristics of yam (Dioscorea cayenensisrotundata) flours. Food Chemistry, 82, 257-264.

3. AOAC. (1990). Official Methods of Analysis of Association of Official Analytical Chemists, 15th edn. Washington DC: Association of Official Analytical Chemists.

4. Babajide, J. M., F. O. Henshaw, and O. B. Oyewole (2008). Effect of yam variety on the pasting properties and sensory attributes of traditional dry-yam and its products. Journal of Food Quality, 31, 295-305.

5. Bahado-Singh, P.S., Riley, C.K., Wheatley, A.O. and Lowe, H.I.C. (2011). Relationship between processing method and the glycemic indices of ten sweet potato (Ipomoea batatas ) cultivars commonly consumed in Jamaica. Journal of Nutrition and Metabolism, Article ID 584832, doi:10.1155/2011/584832

6. Baimey, H., Coyne, D. and Labuschagne, N. (2006). Effect of fertilizer application on yam nematode (Scutellonema bradys) multiplication and consequent damage to yam (Dioscorea spp.) under field and storage conditions in Benin. International Journal of Pest Management, 52, 63-70.

7. BeMiller, J.N. (2010). Carbohydrate analysis. In: Food analysis, 4th edition (Nielsen SS ed.), pp. 147-177, Springer, New York, USA.

8. Bouchon, P. and Aguilera, J. M. (2001). Microstructural analysis of frying of potatoes. International Journal of Food Science and Technology, 36, 669-676.

9. Cardello, A.V. (1995). Food quality: relativity, context and consumer expectations. Food Quality and Preference, 6, 163170 .

10. Chung, H., Lim, H.S. and Lim, S. (2006). Effect of partial gelatinization and retrogradation on the enzymatic digestion of waxy rice starch. Journal of Cereal Science, 43, 353-359.

11. Da-Clarke, U. (2016). Evaluation of index of oiliness, in vitro starch digestibility and consumers' acceptability of fried bitter yam chips. A B.Tech. Project in the Department of Food Science and Technology, Federal University of Technology, Akure, Nigeria.

12. FAOSTAT. (2014). Production statistics on crops. Food and Agriculture Organization of the United Nation, Rome. http://www.fao.org/faostat/en/\#data/QC.

13. Funes, J. and Karel, M. (1981). Free radical polymerization and lipid binding of lysozyme reacted with peroxidizing linoleic acid. Lipids, 16, 347-350.

14. Faulks, R.M. and Bailey, A.L. (1990). Digestion of cooked starches from different food sources by porcine $\alpha$-amylase. Food Chemistry, 36, 191-203.

15. Goñi, I., Garcia-Alonso, A. and Saura-Calixto, F. (1997). A starch hydrolysis procedure to estimate glycemic index. Nutrition Research, 17(3), 427-437.

16. Granfeldt, Y., Bjorck, I., Drews, A. and Tovar, J. (1992). An in vitro procedure based on chewing to predict metabolic responses to starch in cereal and legume products. European Journal of Clinical Nutrition, 46, 649-660.

17. Guoado, I., Demasse, M.A., Etame, L.G., Meyimgo, O., Ruphine, S., Ejoh, A.R. and Fokou, E. (2011). Impact of three processing methods (steaming, roasting on charcoal and frying) on the $\beta$ - carotene and vitamin $\mathrm{C}$ contents of plantain and sweet potato. American Journal of Food Technology, 6(11), $994-1001$.

18. IFIS. (2009). Dictionary of Food Science and Technology, 2nd Edition. Chichester, UK: Wiley-Blackwell, 390 pp.
19. 19. IFT. (1981). Sensory evaluation guide for testing food and beverage products. Food Technology, 35, 5059.

20. Ikanone, C.E.O. and Oyekan, P.O. (2014). Effect of boiling and frying on the total carbohydrate, vitamin $\mathrm{c}$ and mineral contents of Irish (Solanun tuberosum) and sweet (Ipomea batatas) potato tubers. Nigerian Food Journal, 32(2), 33-39.

21. Ikoko, J. and V. Kuri, V. (2007). Osmotic pre-treatment effect on fat intake reduction and eating quality of deep-fried plantain. Food Chemistry, 102, 523-531.

22. 22. Ile, E.I., Craufurd, P.Q., Battey, N.H. and Asiedu, R. (2006). Phases of dormancy in yam tubers (Dioscorea rotundata). Annals of Botany, 97, 497-504.

23. Kemp, S.E., Hollowood, T. and Hort, J. (2009). Sensory evaluation: a practical handbook. John Wiley \& Sons Ltd, Chichester, U.K., pp. 1-3.

24. Kordylas, J.M. (1990). Processing and preservation of tropical and subtropical foods. Macmillan Publishers Ltd., London, U.K., pp. 49-136.

25. Krokida, M. K., Oreopoulou, V., Maroulis, Z. B. and Marinos-Kouris, D. (2001). Effect of osmotic dehydration pretreatment on quality of French fries. Journal of Food Engineering, 49, 339-345.

26. Lawless, H.T. and Heymann, H. (2010). Sensory evaluation of food: principles and practices. 2nd edition, pp. 325-347, Springer: NY, USA.

27. Ludwig, D. S., Majzoub, J.A., Al-Zahrani, A., Dallal, G. E., Blanco, I. and Roberts, S. B. (1999). High glycemic index foods, overeating, and obesity. Pediatrics, 103(3), e26, doi: 10.1542/peds.103.3.e26.

28. 28. Marsha 1l, M.R. (2010). Ash analysis. In: Food Analysis, 4th edition (Nielsen, S.S. ed.), pp. 105-115, Springer, New York, USA.

29. Maskan, M. (2001). Kinetics of colour change of kiwifruits during hot air and microwave drying. Journal of Food Engineering, 48, 169-175.

30. Maziya-Dixon, B., Montes-Lopez, A., Alamu, O., Popoola, I and Asiedu, R. (2014). Enhancing the role of yam in food diversification and income generation. IITA Publication (IITA Research programme on Roots, Tubers and Bananas).

31. McGuire, R.G. (1992). Reporting of objective color measurement. HortScience, 27, $1254-1255$.

32. Miller, J. B., Pang, E. and Bramall, L. (1992). Rice: A high or low glycemic index food? American Journal of Clinical Nutrition, 56(6), 1034-1036.

33. Moskowitz, H. R. (1995). Food Quality: conceptual and sensory aspects. Food Quality and Preference, 6, 157-162.

34. Odenigbo, A., Rahimi, J., Ngadi, M., Amer, S. and Mustafa, A. (2012). Starch digestibility and predicted glycemic index of fried sweet potato cultivars. Functional Foods in Health and Disease, 2(7), 280-289.

35. Onwueme, I. C. and Charles, W.B. (1994). Tropical root and tuber crops: production, perspectives and future prospects. Paper 126-Plant production and protection, pp. 51-114, FAO Publication.

36. Osunde, Z.D. (2008). Minimizing postharvest losses in yam (Dioscorea spp.). In: Using food science and technology to improve nutrition and promote national development (edited by Robertson, G.L. and Lupien, J.R., eds), pp.1-5, International Union of Food Science and Technology.

37. Pedreschi, F., Moyano, P., Kaack, K. and Granby, K. (2005). Colour changes and acrylamide formation in fried potatoes slices. Food Research International, 38, 1-9.

38. Phillips, G.O. and Cui, S.W. (2011). An introduction: evolution and finalisation of the regulatory definition of dietary fibre. Food Hydrocolloids, 25, 139-143.

39. Purseglove, J.W. (1991). Dioscoreacea in tropical crops. monocotyledon. pp. 97-100, New York, USA John Willey \& Sons Publishing Corp. WA

40. Riley, C.K., Bahado-Singh, P.S., Wheatley, A.O., Ahmad, M. H. and Asemota, H. N. (2008). Relationship between the physicochemical properties of starches and the glycemic indices of some Jamaican yams (Dioscorea spp.). Molecular Nutrition and Food Research, 52(11), 1372-1376. 
41. Rojas-Gonzalez, J. A., Avallone, S., Brat, P., Trystram, G., and Bohuon, P. (2006). Effect of deep-fat frying on ascorbic acid, carotenoids and potassium contents of plantain cylinders. International Journal of Food Science and Nutrition, 57(1-2), 123-136.

42. Sánchez-Muniz, F. J. (2012). Dietary fibre and cardiovascular health. Nutricion Hospitalaria, 27(1), 31-45.

43. Simsek, S., Ovando-Martínez, M., Whitney, K. and BelloPérez, L.A. (2012). Effect of acetylation, oxidation and annealing on physicochemical properties of bean starch. Food Chemistry, 134, 1796-1803.

44. Sulaeman, A., Keeler, L., Giraud, D.W., Taylor, S.L., Wehling, R.L. and Driskell, J.A. (2001). Carotenoid content and physicochemical and sensory characteristics of carrot chips deep-fried in different oils at several temperatures. Food Chemistry and Toxicology, 66(9), 1257- 1264.

45. Tufvesson, F., Skrabanja, V., Bjorck, I., Elmstah, H.L. and Eliasson, A.C. (2001). Digestibility of starch systems containing amylose-glycerol monopalmitin complexes. LWT- Food Science and Technology, 34, 131-139.

46. Tumuluru, J.S., Sokhansanj, S., Bandyopadhyay, S., and Bawa, A.S. (2013). Changes in moisture, protein and fat content of fish and rice flour coextrudates during single screw extrusion cooking. Food and Bioprocess Technology, $6(2), 403-415$.

47. Van-Baak, M. A. and Astrup, A. (2009). Consumption of sugars and body weight. Obesity Reviews, 10(1), 9-23.
48. Van-der-Merwe, B., Erasmus, C. Taylor, J.R.N. (2001) African maize porridge: a food with slow in vitro starch digestibility. Food Chemistry, 72, 347-353.

49. Venn, B.J. and Green, T.J. (2007). Glycemic index and glycemic load: measurement issues and their effect on dietdisease relationships. European Journal of Clinical Nutrition, 61(Suppl 1), S122-S131.

50. Washaya, S. Mupangwa, J. F. and Muranda, E. (2016). Nutritional value and utilization of yams (Dioscorea steriscus) by residents of Bindura town, high density suburbs, Zimbabwe. Advances in Agriculture, 1, 1-7.

51. Weller, J.N. and Stanton, K.J. (2002). The establishment and use of a QC analytical/descriptive/consumer measurement model for the routine evaluation of products at manufacturing facilities. Food Quality and Preference, 35, 375-383.

52. Wolever, T.M.S. (2000). Dietary carbohydrates and insulin action in humans. British Journal of Nutrition, 83(1), S97S102.

53. Zhang, X., Tao, N., Wang, X., Chenb, F. and Wang, M. (2015). The colorants, antioxidants, and toxicants from nonenzymatic browning reactions and the impacts of dietary polyphenols on their thermal formation. Food and Function, 6, 345-355.

54. Zia-Ul-Haq, M., Iqba, S., Ahmad, S., Imran, M., Niaz, A. and Bhanger, M.I. (2007). Nutritional and compositional study of desi chickpea (Cicer arietinum L.) cultivars grown in Punjab, Pakistan. Food Chemistry, 105, 1357-1363.

Table 1: Proximate composition (g/100g, dry weight basis) of raw unfried and fried chips produced from bitter yam and sweet potato ${ }^{1}$.

\begin{tabular}{|c|c|c|c|c|c|c|c|c|c|c|c|c|}
\hline \multirow[t]{2}{*}{ Source of sample } & \multicolumn{2}{|c|}{$\begin{array}{l}\text { Moisture } \\
\text { content }\end{array}$} & \multicolumn{2}{|l|}{ Fat } & \multicolumn{2}{|l|}{ Ash } & \multicolumn{2}{|l|}{ Fibre } & \multicolumn{2}{|c|}{ Protein } & \multicolumn{2}{|c|}{ Carbohydrate } \\
\hline & $\begin{array}{l}\text { Raw } \\
\text { unfrie } \\
\text { d chip }\end{array}$ & $\begin{array}{l}\text { Fried } \\
\text { chip }\end{array}$ & $\begin{array}{l}\text { Raw } \\
\text { unfrie } \\
\text { d chip }\end{array}$ & $\begin{array}{l}\text { Fried } \\
\text { chip }\end{array}$ & $\begin{array}{l}\text { Raw } \\
\text { unfrie } \\
\text { d chip }\end{array}$ & $\begin{array}{l}\text { Fried } \\
\text { chip }\end{array}$ & $\begin{array}{l}\text { Raw } \\
\text { unfrie } \\
\text { d chip }\end{array}$ & $\begin{array}{l}\text { Fried } \\
\text { chip }\end{array}$ & $\begin{array}{l}\text { Raw } \\
\text { unfrie } \\
\text { d chip }\end{array}$ & $\begin{array}{l}\text { Fried } \\
\text { chip }\end{array}$ & $\begin{array}{l}\text { Raw } \\
\text { unfrie } \\
\text { d chip }\end{array}$ & $\begin{array}{l}\text { Fried } \\
\text { chip }\end{array}$ \\
\hline Yellow bitter yam & $\begin{array}{l}81.31 \\
\pm 1.22^{\mathrm{a}}\end{array}$ & $\begin{array}{l}6.04 \\
\pm 0.07^{\mathrm{a}}\end{array}$ & $\begin{array}{l}1.76 \\
\pm 0.06^{\mathrm{b}}\end{array}$ & $\begin{array}{l}29.41 \\
\pm 0.07^{\mathrm{a}}\end{array}$ & $\begin{array}{l}7.59 \\
\pm 0.14^{\mathrm{b}}\end{array}$ & $\begin{array}{l}1.86 \\
\pm 0.03^{b}\end{array}$ & $\begin{array}{l}12.46 \\
\pm 0.24^{\mathrm{a}}\end{array}$ & $\begin{array}{l}4.45 \\
\pm 0.02^{\mathrm{c}}\end{array}$ & $\begin{array}{l}11.88 \\
\pm 0.32^{\mathrm{a}}\end{array}$ & $\begin{array}{l}2.44 \\
\pm 0.02^{\mathrm{b}}\end{array}$ & $\begin{array}{l}66.31 \\
\pm 0.22^{\mathrm{c}}\end{array}$ & $\begin{array}{l}61.85 \\
\pm 0.17^{\mathrm{a}}\end{array}$ \\
\hline White bitter yam & $\begin{array}{l}80.59 \\
\pm 0.87^{\mathrm{a}}\end{array}$ & $\begin{array}{l}5.32 \\
\pm 0.33^{b}\end{array}$ & $\begin{array}{l}2.45 \\
\pm 0.09^{\mathrm{a}}\end{array}$ & $\begin{array}{l}28.93 \\
\pm 0.31^{\mathrm{a}} \\
\mathrm{b}\end{array}$ & $\begin{array}{l}9.89 \\
\pm 0.31^{\text {a }}\end{array}$ & $\begin{array}{l}1.66 \\
\pm 0.13^{\mathrm{c}}\end{array}$ & $\begin{array}{l}9.07 \\
\pm 0.36^{b}\end{array}$ & $\begin{array}{l}7.38 \\
\pm 0.04^{\mathrm{a}}\end{array}$ & $\begin{array}{l}10.08 \\
\pm 0.21^{b}\end{array}$ & $\begin{array}{l}3.32 \\
\pm 0.06^{\mathrm{a}}\end{array}$ & $\begin{array}{l}68.51 \\
\pm 0.48^{b}\end{array}$ & $\begin{array}{l}58.71 \\
\pm 0.05^{b}\end{array}$ \\
\hline $\begin{array}{l}\text { Sweet potato } \\
\text { (control) }\end{array}$ & $\begin{array}{l}76.29 \\
\pm 1.11^{\mathrm{b}}\end{array}$ & $\begin{array}{l}4.64 \\
\pm 0.08^{\mathrm{c}}\end{array}$ & $\begin{array}{l}1.89 \\
\pm 0.09^{\mathrm{b}}\end{array}$ & $\begin{array}{l}28.51 \\
\pm 0.09^{b}\end{array}$ & $\begin{array}{l}7.64 \\
\pm 0.25^{\mathrm{b}}\end{array}$ & $\begin{array}{l}2.91 \\
\pm 0.07^{\mathrm{a}}\end{array}$ & $\begin{array}{l}12.78 \\
\pm 0.19^{\mathrm{a}}\end{array}$ & $\begin{array}{l}6.01 \\
\pm 0.03^{b}\end{array}$ & $\begin{array}{l}7.93 \\
\pm 0.17^{\mathrm{c}}\end{array}$ & $\begin{array}{l}0.55 \\
\pm 0.04^{\mathrm{c}}\end{array}$ & $\begin{array}{l}69.76 \\
\pm 0.37^{\mathrm{a}}\end{array}$ & $\begin{array}{l}62.04 \\
\pm 0.14^{\mathrm{a}}\end{array}$ \\
\hline
\end{tabular}

${ }^{1}$ Results are mean values of triplicate determination \pm standard deviation. Mean value within the same column having the same letter are not significantly different at $\mathrm{p}<0.05$. 
Proximate Composition, Colour Characteristics, Index of Oiliness and Estimated Glycemic Index of Deep-fried Bitter Yam (Dioscorea dumentorum) Chips

Table 2: Colour characteristics and oiliness index of fried chips produced from bitter yam and sweet potato ${ }^{1}$.

\begin{tabular}{llllll}
\hline Source of fried chips & $\mathbf{L}^{*}$ & $\mathbf{a}^{*}$ & $\mathbf{b}^{*}$ & \multicolumn{1}{c}{$\begin{array}{l}\text { Browning index } \\
(\mathbf{B I})\end{array}$} & $\begin{array}{l}\text { Oiliness index } \\
\left(\mathbf{c m}^{\mathbf{2}}\right)\end{array}$ \\
\hline Yellow bitter yam & $49 \pm 1^{\mathrm{c}}$ & $12 \pm 1^{\mathrm{b}}$ & $19 \pm 1^{\mathrm{a}}$ & $66.2 \pm 3.2^{\mathrm{a}}$ & $29.1 \pm 4.0^{\mathrm{b}}$ \\
White bitter yam & $59 \pm 3^{\mathrm{a}}$ & $13.2 \pm 0.8^{\mathrm{b}}$ & $17.4 \pm 0.7^{\mathrm{b}}$ & $50.8 \pm 1.6^{\mathrm{b}}$ & $21.6 \pm 2.0^{\mathrm{c}}$ \\
Sweet potato (control) & $54 \pm 2^{\mathrm{b}}$ & $15.1 \pm 0.7^{\mathrm{a}}$ & $15.2 \pm 0.9^{\mathrm{c}}$ & $52.8 \pm 2.2^{\mathrm{b}}$ & $36.1 \pm 7.0^{\mathrm{a}}$
\end{tabular}

${ }^{1}$ Results are mean values of triplicate determinations \pm standard deviation. Mean value within the same column having the same letter are not significantly different at $\mathrm{p}<0.05$.

Table 3: Estimated glycemic index of fried chips from bitter yam and sweet potato.

\begin{tabular}{|c|c|c|c|}
\hline Source of sample & $\begin{array}{l}\text { Total glucose released } \\
\text { during hydrolysis }(\mathrm{mg} / \mathrm{g})\end{array}$ & $\begin{array}{l}\text { Hydrolysis index } \\
\text { (HI, \%) }\end{array}$ & $\begin{array}{l}\text { Estimated glycemic index } \\
(\mathrm{eGI}, \%)\end{array}$ \\
\hline $\begin{array}{l}\text { Fried chip of yellow bitter } \\
\text { yam }\end{array}$ & $94.6 \pm 3.1^{\mathrm{b}}$ & $72.5 \pm 3.8^{\mathrm{a}}$ & $79.5 \pm 2.6^{\mathrm{a}}$ \\
\hline Fried chip of white bitter yam & $82.3 \pm 4.5^{\mathrm{c}}$ & $63.1 \pm 2.1^{\mathrm{b}}$ & $74.4 \pm 1.8^{\mathrm{b}}$ \\
\hline $\begin{array}{l}\text { Fried chip of sweet potato } \\
\text { (control) }\end{array}$ & $76.2 \pm 2.6^{\mathrm{cd}}$ & $58.4 \pm 2.9^{\mathrm{bc}}$ & $71.8 \pm 2.1^{\mathrm{bc}}$ \\
\hline White bread (reference) & $130.4 \pm 4.3^{\mathrm{a}}$ & - & - \\
\hline
\end{tabular}

Table 4: Sensory quality rating of fried chips produced from bitter yam and sweet potato ${ }^{1}$.

\begin{tabular}{|c|c|c|c|c|c|c|}
\hline $\begin{array}{l}\text { Source of fried } \\
\text { chips }\end{array}$ & \multicolumn{6}{|c|}{ Sensory factor } \\
\hline White bitter yam & $5.8 \pm 0.7^{\mathrm{bc}}$ & $6.4 \pm 0.5^{\mathrm{b}}$ & $6.5 \pm 0.4^{\mathrm{b}}$ & $6.9 \pm 0.6^{\mathrm{a}}$ & $7.2 \pm 0.2^{\mathrm{a}}$ & $6.5 \pm 0.3^{b}$ \\
\hline $\begin{array}{l}\text { Sweet potato } \\
\text { (control) }\end{array}$ & $7.4 \pm 0.4^{\mathrm{a}}$ & $7.4 \pm 0.2^{\mathrm{a}}$ & $7.7 \pm 0.4^{\mathrm{a}}$ & $7.1 \pm 0.4^{\mathrm{a}}$ & $6.1 \pm 0.4^{\mathrm{b}}$ & $8.1 \pm 0.4^{\mathrm{a}}$ \\
\hline
\end{tabular}

${ }^{1}$ Results are mean values from 50 panelists \pm standard deviation. Mean value within the same column having the same letter are not significantly different at $p<0.05$. 


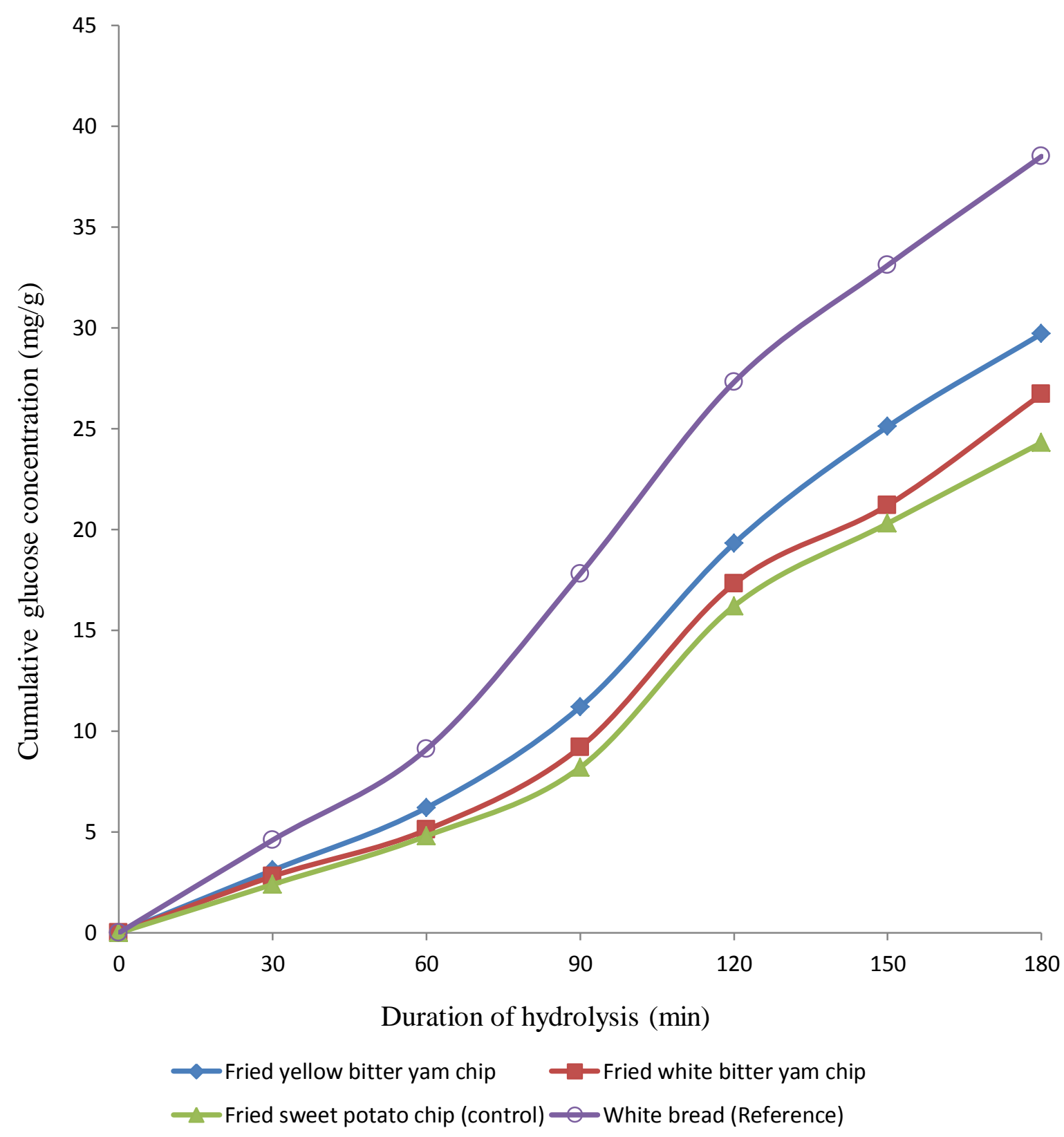

Figure 1: Rate of in-vitro starch digestibility of fried chips from bitter yam and sweet potato compared with that of white bread (reference). 